\title{
Middle-term expansion of hematopoietic cord blood cells with new human stromal cell line feeder-layers and different cytokine cocktails
}

\author{
S. DE ANGELI ${ }^{1}$, S. BAIGUERA ${ }^{2}$, L. DEL PUP ${ }^{1}$, E. PAVAN ${ }^{1}$, G.B. GAJO ${ }^{1}$, R. DI LIDDO ${ }^{2}$, \\ M.T. CONCONI ${ }^{2}$, C. GRANDI ${ }^{2}$, O. SCHIAVON ${ }^{2}$ and P.P. PARNIGOTTO ${ }^{2}$ \\ ${ }^{1}$ Treviso Cord Blood Bank and Hematopoietic Cell Culture Laboratory, Transfusional Center, Treviso Regional Hospital, \\ U.L.S.S. 9, Treviso; ${ }^{2}$ Department of Pharmaceutical Sciences, University of Padua, Padua, Italy
}

Received May 8, 2009; Accepted July 3, 2009

DOI: $10.3892 /$ ijmm_00000301

\begin{abstract}
Cord blood (CB) is a source of hematopoietic stem cells (HSCs) and is an alternative to bone marrow for allogenic transplantation in patients with hematological disorders. The improvement of HSC in vitro expansion is one of the main challenges in cell therapy. Stromal components and soluble factors, such as cytokines, can be useful to induce in vitro cell expansion. Hence, we investigated whether feeder-layers from new stromal cell lines and different exogenous cytokine cocktails induce HSC expansion in middle-term cultures. CB HSC middle-term expansion was carried out in co-cultures on different feeder-layers exposed to three different cytokine cocktails. CB HSC expansion was also carried out in stromafree cultures in the presence of different cytokine cocktails. Clonogenic tests were performed, and cell growth levels were evaluated. Moreover, the presence of VCAM-1 mRNA was assessed, and the mesenchymal cell-like phenotype expression was detected. All feeder-layers were able to induce a significant clonogenic growth with respect to the control culture, and all of the cytokine cocktails induced a significant increase in $\mathrm{CB}$ cell expansion indexes, even though no potential variation dependent on their composition was noted. The modulative effects of the different cocktails, exerted on each cell line used, was dependent on their composition. Finally, all cell lines were positive for CD73, CD117 and CD309, similar to mesenchymal stem cells present in adult bone marrow and in other human tissues, and negative for the hematopoietic markers. These data indicate that our cell lines have, not only a stromal cell-like phenotype, but also a mesenchymal cell-like phenotype, and they have the potential to support in vitro expansion of CB HSCs. Moreover,
\end{abstract}

Correspondence to: Dr Sergio De Angeli, Treviso Cord Blood Bank and Hematopoietic Cell Culture Laboratory, Transfusional Center, Treviso Regional Hospital, U.L.S.S. 9., Piazzale dell'Ospedale 21, I-31100 Treviso, Italy

E-mail: sdeangeli@ulss.tv.it

Key words: hematopoietic cord blood cells, in vitro expansion, stromal feeder-layers, cytokines exogenous cytokines can be used in synergism with feederlayers to improve the expansion levels of CB HSCs in preparation for their clinical use in allogenic transplantation.

\section{Introduction}

In the past decade important knowledge of hematopoietic system biology has been acquired. It is known that bone marrow contains a pluripotent stem cell population capable of self renewal and generation, by different maturation pathways; several subsets characterized by functional hierarchy $(1,2)$. The balance between two opposite fates seems to depend on a complex network of homeostatic signals, largely still unknown, arising from the bone marrow microenvironment (3). Several studies suggest that proliferation and differentiation of hematopoietic stem cells (HSCs) result from direct cell interaction with stromal components, including stromal cells or extracellular matrix (4-7), and from the inductive action of paracrine/autocrine soluble factors, such as interleukins or cytokines $(8,9)$.

Co-culture with stromal feeder-layers, which creates an artificial microenvironment favoring cell growth, is one of the most promising in vitro approaches to enhance the expansion of hematopoietic cells (10-13). In fact, stromal feeder-layers, not only produce several cytokines, but also synthesize proteoglycans, which can adsorb growth factors, thereby modulating their presentation rate to hematopoietic cells and enhancing their biological efficiency (14-16).

Identification, cloning, and production of human recombinant cytokines have greatly improved in vitro HSC manipulation by middle- or long-term expansion methods using culture media supplemented with cytokine cocktails $(17,18)$. Nevertheless, the optimal cytokine combinations for in vitro expansion of hematopoietic stem/progenitor cells have not yet been determined, nor has any definitive continuous expansion method been standardized. Moreover, HSCs and progenitor cells derived from different sources (bone marrow, cord blood and peripheral blood mobilized cells) seem to be differentially responsive to these growth factors (19-21).

It is known that cord blood (CB) is a source of HSCs as an alternative to bone marrow for allogenic transplantation 
in patients with hematological disorders (22-24). There is evidence for a direct positive correlation between the number of reinfused $\mathrm{CB}$ cells and the percentage of success of transplantation $(22,25)$. However, CB HSCs are very naive, and the number available in a single $\mathrm{CB}$ unit is much too limited to ensure a rapid, stable and lasting medullary repopulation in patients with a body weight exceeding $40 \mathrm{~kg}$ $(23,24)$. Therefore, improvement of the in vitro expansion of CB HSCs represents one of the main challenges of cell therapy.

Preclinical and clinical studies on $\mathrm{CB}$ have highlighted different cytokine cocktails $(22,26)$, novel molecules $(27,28)$ and sophisticated culture systems to better perform expansion of CB HSCs $(30,31)$.

To achieve this goal, the co-culture of CB HSCs with feeder-layers composed of stromal cells seems to be an attractive approach. We previously isolated and characterized two human embryo liver cell lines: one stabilized (BAEP2W) and one immortalized (BAEP2SV40) by retroviral transduction with SV40 large T antigen (32). Moreover, conditioned media from these new human stromal immortalized cell lines, derived from bone marrow (HM1SV40 and HM2SV40 cell lines) and umbilical cord tissue (HCB1SV40 cell line), were able to enhance clonal growth of human CB HSCs (33).

Hence, it seemed worthwhile to characterize these cellular lines and to investigate whether i) feeder-layers of these cell lines induce the expansion of cord blood HSCs/committed progenitors in middle-term culture and ii) whether different exogenous cytokine cocktails enhance the inductive effect of these feeder-layers.

\section{Materials and methods}

Mononucleated (MN) cell isolation. Cord blood (CB) units were obtained at the end of full-term deliveries according to the Foundation for the Accreditation of Cell Therapy (FACT) protocols and after obtaining informed consent. Samples were processed within $48 \mathrm{~h}$ of collection. After the clamping and cutting of the cord, blood samples were drained into sterile collection bags containing the anticoagulant citratephosphate dextrose. After blood centrifugation at 2,500 rpm for $20 \mathrm{~min}$ at $20^{\circ} \mathrm{C}$, the low-density $\mathrm{MN}$ cell fraction of the CB unit was obtained by collecting the cells located at the interface of a one-step Ficoll-Histoprep $(1.077 \mathrm{~g} / \mathrm{ml})$ gradient (34). Cells were washed three times in citrate-phosphate buffered salt (PBS) solution, and resuspended in Stemline Hematopoietic Stem Cell Expansion Medium (Sigma) containing $4 \mathrm{mM}$ glutamine (Sigma), $100 \mathrm{U} / \mathrm{ml}$ penicillin (Sigma), $100 \mu \mathrm{g} / \mathrm{ml}$ streptomycin (Sigma), $2.5 \mu \mathrm{g} / \mathrm{ml}$ amphotericin B (Life Technologies) and $0.20 \mathrm{U} / \mathrm{ml}$ deoxyribonuclease I (Sigma) (DNase Complete Stemline II Haematopoietic Stem Cell Expansion Medium). The number of MN cells was determined using a hematocytometric method. Cells were then frozen in culture medium containing $10 \%$ DMSO (Sigma). For the experiments, MN cells were thawed and washed in RPMI-1640 medium (Gibco) with $10 \%$ human albumin. Cells were then resuspended in DNase Complete Stemline Medium.

Cell line cultures and feeder-layer preparation. Human bone marrow-derived HM1SV40 and HM2SV40, umbilical cord- derived HCB1SV40, and fetal liver-derived BAEP2SV40 and BAEP2W cell lines were obtained as previously described $(32,33)$. The BAEP2W cell line was obtained by successive serial passages of the secondary cultures, while the other cell lines were immortalized by retroviral transduction of secondary cultures with SV40 large T antigen gene encoding a sensitive temperature protein $(32,33)$.

Cells were cultured in TBF1 medium composed of DMEM supplemented with $10 \% \mathrm{FBS}, 10 \% \mathrm{HS}, 1 \mathrm{mM}$ sodium pyruvate, $10 \mathrm{ng} / \mathrm{ml} \mathrm{EGF,} 1 \mathrm{ng} / \mathrm{ml} \mathrm{FGF,} 0.33 \mathrm{Ul} / \mathrm{ml}$ heparin, $100 \mathrm{U} / \mathrm{ml}$ penicillin, $100 \mu \mathrm{g} / \mathrm{ml}$ streptomycin, $100 \mu \mathrm{g} / \mathrm{ml}$ kanamycin and $2.5 \mu \mathrm{g} / \mathrm{ml}$ amphotericin B.

The M2-10B4 murine fibroblast cell line transfected with hIL-3 and hG-CSF cytokine coding genes (35), was used as the control and was cultured in LTC-IC medium (4) consisting of DMEM supplemented with $12.5 \% \mathrm{FBS}, 12.5 \%$ HS, 0.1 mM 2- 3 mercaptoethanol, $0.016 \mathrm{mM}$ folic acid, $0.16 \mathrm{mM}$ inositol, $100 \mathrm{U} / \mathrm{ml}$ penicillin, $100 \mu \mathrm{g} / \mathrm{ml}$ streptomycin, $100 \mu \mathrm{g} / \mathrm{ml}$ kanamycin and $2.5 \mu \mathrm{g} / \mathrm{ml}$ amphotericin B.

To obtain a feeder-layer, $1 \times 10^{5}$ cells/well were plated in 24-well Beal plates, previously treated for $2 \mathrm{~h}$ at $39^{\circ} \mathrm{C}$ with $1 \%$ bovine gelatine. After an overnight incubation at $37^{\circ} \mathrm{C}$, the cultures were treated for $4 \mathrm{~h}$ with $1 \mu \mathrm{g} / \mathrm{ml}$ mitomycin C. After washing, feeder-layers were cultured with Stemline II Hematopoietic Stem Cell Expansion Medium (Sigma) supplemented with $4 \mathrm{mM}$ glutamine, $100 \mathrm{U} / \mathrm{ml}$ penicillin, $100 \mu \mathrm{g} /$ $\mathrm{ml}$ streptomycin, $100 \mu \mathrm{g} / \mathrm{ml}$ kanamycin and $2.5 \mu \mathrm{g} / \mathrm{ml}$ amphotericin B (Complete Stemline II Hematopoietic Stem Cell Expansion Medium). The mitomycin $C$ treatment was repeated 2-fold for each cell line, except for the BAEP2W cell line which was treated only once with $0.5 \mu \mathrm{g} / \mathrm{ml}$ mitomycin $\mathrm{C}$.

Detection of vascular cell adhesion molecule (VCAM)-1. VCAM-1 expression in the cell lines was detected by reverse transcription (RT)-polymerase chain reaction (PCR). Cell lines were cultured at 33,37 or $39^{\circ} \mathrm{C}$, and at confluence, they were incubated for $24 \mathrm{~h}$ in serum-free DMEM. Total RNA was extracted from $1 \times 10^{7}$ cells using the RNAzol B Kit (Boehringer), and reverse transcribed to cDNA as previously described (36). Using a specific primer, expression of VCAM-1 was assayed by PCR (32). Briefly, in a DNA Thermal Cycler 480 (Perkin Elmer) a denaturation step at $94^{\circ} \mathrm{C}$ for $1 \mathrm{~min}$, annealing for $2 \mathrm{~min}$ and an extension step at $72^{\circ} \mathrm{C}$ for $3 \mathrm{~min}$ for a total of 40 cycles were carried out. The primer sequence, annealing temperature and predicted size of the PCR products were respectively: sense 5'-AGAATATA GAGTTTTTGGAGGATAC-3'; antisense 5'-CTTCTTTTCT GCTTCTTCCA-3', $52^{\circ} \mathrm{C}$ and 432 bp.

Controls for PCR included reactions without cDNA $\left(\mathrm{H}_{2} \mathrm{O}\right)$ or prior RT of the RNA, as well as mRNA detection of the housekeeping gene $B$-actin. The amplification products were separated by $2 \%$ agarose gel electrophoresis and visualized with ethidium bromide staining in a Molecular Analyst Bio-Rad apparatus (BioRad).

Immunocytochemistry (ICC). Samples were prepared by cytocentrifugation and fixed in a methanol 40 vol-5\% $\mathrm{H}_{2} \mathrm{O}_{2}$ solution for $10 \mathrm{~min}$. Samples were labelled using the avidin- 
Table I. Primary antibodies and their dilution.

\begin{tabular}{ll}
\hline Antibody & Dilution in \\
& PBS:BSA
\end{tabular}

\begin{tabular}{lc}
\hline Anti-EGF polyclonal rabbit IgG & $1: 2$ \\
Anti-EGF-R clone 29.1 & $1: 5$ \\
Anti-FGF clone 3H3 & $1: 2$ \\
Anti-FGF-R clone VBS-7 & $1: 2$ \\
Anti-AM polyclonal goat IgG & $1: 5$ \\
Anti-RAMP2 polyclonal goat IgG & $1: 5$ \\
Anti-ET-1 & $1: 50$ \\
Anti-ETAR polyclonal goat IgG & $1: 5$ \\
Anti-ETBR polyclonal goat IgG & $1: 50$ \\
Anti-CD14 monoclonal & $1: 50$ \\
Anti-CD15 monoclonal & $1: 50$ \\
Anti-CD33 clone WM53 & $1: 50$ \\
Anti-CD34 monoclonal & $1: 50$ \\
Anti CD42b clone AK2 & $1: 50$ \\
Anti-CD71 monoclonal & $1: 50$ \\
Anti-5'-nucleotidase polyclonal rabbit IgG & $1: 50$ \\
Anti-Thy polyclonal rabbit IgG & $1: 50$ \\
Anti-CD105 (anti-endoglin monoclonal) & $1: 50$ \\
Anti-ACTR-1 polyclonal goat IgG & $1: 50$ \\
Anti-c-kit polyclonal rabbit IgG & $1: 50$ \\
Anti-HLA-DR monoclonal & $1: 50$ \\
Anti-Flk-1 monoclonal & $1: 50$ \\
Anti-STRO-1 clone & $1: 50$ \\
Anti-collagen type I polyclonal goat IgG & $1: 50$ \\
Anti- $\alpha$-actin clone 1A4 & $1: 25$ \\
Anti-desmin clone D33 & $1: 100$ \\
Anti-fibronectin clone FN-3E2 & $1: 400$ \\
Anti-laminin clone LAM-89 & $1: 1000$ \\
\hline & \\
\hline & \\
& \\
&
\end{tabular}

biotin amplified immunoperoxidase method, using the Large Volume Dako LSAB+ Peroxidase Kit (Dako, Glostrup, Denmark). The primary antibodies and their dilutions are shown in Table I. Positive and negative controls were carried out as previously described $(27,32)$.

Middle-term expansion and clonogenic assay. MN cells ( $7 \times 10^{5} /$ well) were placed on feeder-layers previously treated with mitomycin $\mathrm{C}$ with or without the following cytokine cocktails (CKTs): i) CKT A: IL-3 (2 ng/ml), IL-6 (2 ng/ml), SCF $(0.5 \mathrm{ng} / \mathrm{ml})$, Flt $3(0.5 \mathrm{ng} / \mathrm{ml})$; ii) CKT B: IL-3 $(2 \mathrm{ng} /$ $\mathrm{ml})$, IL-6 (2 ng/ml), SCF $(0.5 \mathrm{ng} / \mathrm{ml})$, Flt $3(0.5 \mathrm{ng} / \mathrm{ml})$, TPO (0.5 ng/ ml); iii) CKT C: IL-3 (2 ng/ml), IL-6 (2 ng/ml), SCF $(0.5 \mathrm{ng} / \mathrm{ml})$, Flt $3(0.5 \mathrm{ng} / \mathrm{ml})$, TPO $(0.5 \mathrm{ng} / \mathrm{ml}), \mathrm{IL}-1 \beta(400 \mathrm{pg} /$ $\mathrm{ml})$, GM-CSF (0.5 ng/ml), G-CSF (0.5 ng/ml), EPO (3 U/ml).

$\mathrm{MN}$ cell cultures without feeder layers and/or treated with cytokines were used as controls. The cultures were grown in Stemline II Hematopoietic Stem Cell Expansion Medium for 14 days at $37^{\circ} \mathrm{C}$ in a $95 \%$ air-5\% $\mathrm{CO}_{2}$ atmosphere. Cultures were observed daily using an inverted Axiovert 100 microscope (Zeiss, Germany). At the end of the incubation period, both non-adherent and adherent cells were collected from each well; after washing with $2 \mathrm{mM} \mathrm{CaCl}_{2}$ in $0.9 \% \mathrm{NaCl}$, the latter ones were incubated for $30 \mathrm{~min}$ at $37^{\circ} \mathrm{C}$ with $2.4 \mathrm{U} / \mathrm{ml}$ Dispase II and scraped with plastic Pasteur pipettes. Cells were then centrifuged for $10 \mathrm{~min}$ at $4^{\circ} \mathrm{C}$ at $1800 \mathrm{rpm}$, and the pellets were resuspended in Stemline II Hematopoietic Stem Cell Expansion Medium. Clonogenic tests were carried out according to the Miller and Lai method (37). Aliquots of a $100-\mu 1$ cell suspension were seeded in 24-well Beal plates in previously distributed Methocult GF H4435 semi-solid medium (StemCell Technologies), composed of Iscove's MDM supplemented with $1 \%$ methylcellulose, $30 \%$ FBS, $1 \%$ BSA, HS, $10^{-4}$ M 2- $\beta$ mercaptoethanol, $2 \mathrm{mM}$ L-glutamine, $50 \mathrm{ng} / \mathrm{ml} \mathrm{rhSCF}, 20 \mathrm{ng} / \mathrm{ml} \mathrm{rhGM}-\mathrm{CSF}, 20 \mathrm{ng} / \mathrm{ml} \mathrm{rhIL}-3,20 \mathrm{ng} /$ $\mathrm{ml} \mathrm{rhIL}-6,20 \mathrm{ng} / \mathrm{ml} \mathrm{rhG}-\mathrm{CSF}$ and $3 \mathrm{U} / \mathrm{ml} \mathrm{rhEPO}$. After a 14day incubation period at $37^{\circ} \mathrm{C}$, the cultures were observed using an inverted Axiovert 100 microscope to count the colony forming units (CFUs) (38).

Statistical analysis. Clonogenic test data, obtained from 10 experiments and expressed as mean values $\pm \mathrm{SD}$, were first subjected to Curtosi, Sweknees and Barlett statistical tests. Then, to compare the different experimental groups, the nonparametric tests for paired data, Friedman and Dunn's multiple comparison tests, were performed by assuming $\mathrm{p}<0.05$ (GraphPad Prism 4.0).

The expansion indexes (E.I.s) used to evaluate the growth levels in the cultures with the cytokine cocktails and in the co-cultures were calculated as follows:

\section{E.I. $=\underline{\text { CFU mean number of screening cultures, }}$ CFU mean number of control cultures}

where screening cultures were the cultures treated with cytokine cocktails and co-cultures with or without cytokines.

The relative expansion indexes (E.I.R.s) used to analyze the interaction between the cytokine cocktails and the stromal feeder-layers were calculated as follows:

E.I.R.FL $=\underline{\text { CFU mean number of co-cultures treated with cytokines }}$ CFU mean number of no treated co-cultures

E.I.R. ${ }_{\mathrm{CKT}}=\underline{\mathrm{CFU} \text { mean number of co-cultures treated with cytokines }}$ CFU mean number of cultures treated with cytokines

Moreover, in order to evaluate the expansion with respect to the M2-10B4 cell line, the relative expansion indexes were calculated as follows:

E.I.R.M2-10B4 $=\underline{\mathrm{CFU} \text { mean number of co-cultures treated with cytokines }}$ CFU mean number of M2-10B4 co-cultures

\section{Results}

RT-PCR was used to demonstrate the expression of adhesion factor VCAM-1 in HM1SV40, HM2SV40 and HCB1SV4O cell lines as previously described for immortalized embryo liver BAEP2SV40 cells (data not shown) (32).

As shown in Table II, ICC revealed that all cell lines used for feeder-layers were positive for FGF, FGF receptor (FGF-R), CD73, Thy1, ACTR-1, FLK-1, c-kit (except for HCB1SV40), laminin, collagen type I, AM, RAMP2 (AM receptor) and ET-1. ET receptors (ETAR and ETBR) were expressed only in the fetal liver and in HM2SV40 derived cell lines. 
Table II. Immunocytochemical data for BAEP2-WILD, BAEP2SV40, HM1SV40, HM2SV40 and HCB1SV40 cell lines.

\begin{tabular}{|c|c|c|c|c|c|}
\hline Antibody & BAEP2-WILD & BAEP2SV40 & HM1SV40 & HM2SV40 & HCB1SV40 \\
\hline Anti-EGF polyclonal rabbit IgG & $2+\mathrm{Ho}$ & $1+\mathrm{Ho}$ & - & $1+\mathrm{R}$ & $1+\mathrm{He}$ \\
\hline Anti-EGF-R clone 29.1 & $2+\mathrm{Ho}$ & & - & - & - \\
\hline Anti-FGF clone $3 \mathrm{H} 3$ & $3+\mathrm{Ho}$ & $3+\mathrm{Ho}$ & $2+\mathrm{Ho}$ & $3+\mathrm{Ho}$ & $3+\mathrm{Ho}$ \\
\hline Anti-FGF-R clone VBS-7 & $3+\mathrm{Ho}$ & $2+\mathrm{Ho}$ & $2+\mathrm{Ho}$ & $3+\mathrm{Ho}$ & $3+\mathrm{He}$ \\
\hline Anti-AM polyclonal goat IgG & $3+\mathrm{Ho}$ & $2+\mathrm{Ho}$ & $2+\mathrm{Ho}$ & $2+\mathrm{Ho}$ & $2+\mathrm{Ho}$ \\
\hline Anti-RAMP2 polyclonal goat IgG & $3+\mathrm{Ho}$ & $2+\mathrm{Ho}$ & $2+\mathrm{Ho}$ & $3+\mathrm{Ho}$ & $2+\mathrm{Ho}$ \\
\hline Anti-ET-1 & $3+\mathrm{Ho}$ & $3+\mathrm{Ho}$ & $3+\mathrm{Ho}$ & $3+\mathrm{Ho}$ & $3+\mathrm{Ho}$ \\
\hline Anti-ETAR polyclonal goat IgG & $1+\mathrm{He}$ & $1+\mathrm{He}$ & - & $2+\mathrm{Ho}$ & - \\
\hline Anti-ETBR polyclonal goat IgG & $2+\mathrm{He}$ & $2+\mathrm{Ho}$ & - & $2+\mathrm{Ho}$ & - \\
\hline Anti-CD14 monoclonal & - & NE & - & - & - \\
\hline Anti-CD15 monoclonal & - & - & - & - & - \\
\hline Anti-CD33 clone WM53 & - & - & - & - & $1+\mathrm{He}$ \\
\hline Anti-CD34 monoclonal & - & - & - & - & - \\
\hline Anti-CD42b clone AK2 & - & - & - & $1+\mathrm{He}$ & - \\
\hline Anti-CD71 monoclonal & - & - & - & - & - \\
\hline Anti-5'-nucleotidase polyclonal rabbit IgG & $2+\mathrm{Ho}$ & $3+\mathrm{Ho}$ & $2+\mathrm{Ho}$ & $2+\mathrm{Ho}$ & $2+\mathrm{Ho}$ \\
\hline Anti-Thy polyclonal rabbit IgG & $2+\mathrm{Ho}$ & NE & $1+\mathrm{He}$ & $3+\mathrm{Ho}$ & $3+\mathrm{Ho}$ \\
\hline Anti-CD105 (anti-endoglin monoclonal) & - & - & - & - & - \\
\hline Anti-ACTR-1 polyclonal goat IgG & $3+\mathrm{Ho}$ & $3+\mathrm{Ho}$ & $2+\mathrm{Ho}$ & $3+\mathrm{Ho}$ & $2+\mathrm{Ho}$ \\
\hline Anti-c-kit polyclonal rabbit IgG & $2+\mathrm{Ho}$ & NE & $2+\mathrm{Ho}$ & $2+\mathrm{He}$ & - \\
\hline Anti-HLA-DR monoclonal & - & - & - & - & - \\
\hline Anti-Flk-1 monoclonal & $2+\mathrm{Ho}$ & $2+\mathrm{Ho}$ & $1+\mathrm{He}$ & $3+\mathrm{Ho}$ & $1+\mathrm{Ho}$ \\
\hline Anti-STRO-1 clone & - & - & - & - & - \\
\hline Anti-collagen type I polyclonal goat IgG & $2+\mathrm{Ho}$ & $3+\mathrm{Ho}$ & $2+\mathrm{Ho}$ & $1+\mathrm{R}$ & - \\
\hline Anti- $\alpha$-actin clone $1 \mathrm{~A} 4$ & $1+\mathrm{R}$ & $2+\mathrm{R}$ & - & $1+\mathrm{R}$ & $2+\mathrm{He}$ \\
\hline Anti-desmin clone D33 & - & - & - & - & - \\
\hline Anti-fibronectin clone FN-3E2 & - & $2+\mathrm{Ho}$ & - & - & $2+\mathrm{R}$ \\
\hline Anti-laminin clone LAM-89 & $2+\mathrm{Ho}$ & $2+\mathrm{Ho}$ & - & $3+\mathrm{Ho}$ & $3+\mathrm{Ho}$ \\
\hline
\end{tabular}

The intensity of stained cell positivity was evaluated by assigning a score between $1+$ and $3+$. Samples were defined as not executed (NE), 'homogeneous' (Ho), 'heterogeneous' $(\mathrm{He})$ or with 'rare positive cells' (R) when the number of positive cells was between 81 and $100 \%$, between 20 and $80 \%$ and $<20 \%$ of total cells, respectively.

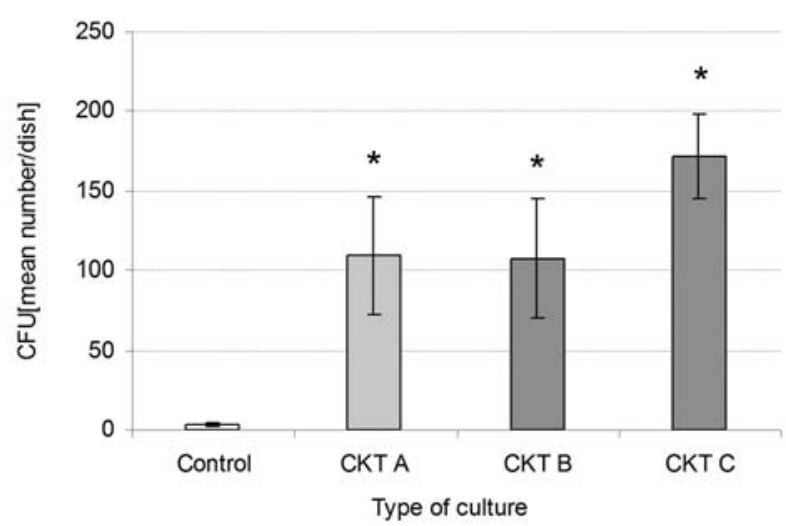

Figure 1. Effects of CKT treatment on MN clonal growth with respect to MN control cultures. Bars are means \pm SD $(n=10)$. * $p<0.05$; Friedman and Dunn's multiple comparison tests.
MN cultures were treated with each CKT with the stromal feeder-layers, and the CFU number was evaluated. Cytokine supplementation significantly $(\mathrm{p}<0.05)$ enhanced the number of CFUs in comparison with that determined in cultures grown with medium alone (Fig. 1). The E.I.s were 31 for CKT $\mathrm{A}$ and $\mathrm{B}$ and 49 for CKT C. Hence, the increase in CFUs induced by $\mathrm{CKT} \mathrm{C}$ was higher than the increases observed using other CKTs. Stromal feeder layers significantly $(\mathrm{p}<0.05)$ enhanced the number of CFUs in comparison with the number determined in cultures grown in medium alone (Fig. 2). Among the various cultural conditions, co-cultures with M2-10B4 and HCB1SV40 cells were more effective. In fact, the E.I.s of fetal liver- and bone marrow-derived cell lines ranged from 3 to 7, while the E.I.s of M2-10B4 and HCB1SV40 cells were 28 and 36, respectively.

The addition of all cytokine combinations to the cocultures significantly $(\mathrm{p}<0.05)$ increased the clonogenic 


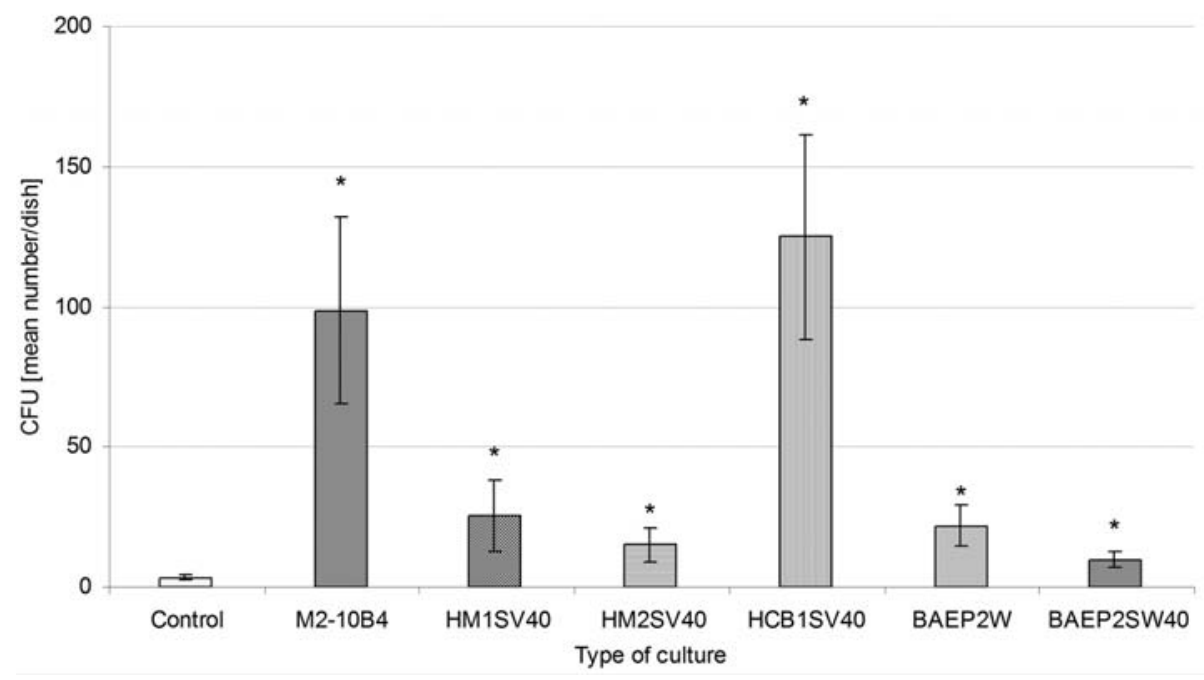

Figure 2. Effects of stromal feeder-layers on MN cell clonal growth with respect to MN control cultures. Bars are means \pm SD ( $n=10)$. " $p<0.05$; Friedman and Dunn's multiple comparison tests.

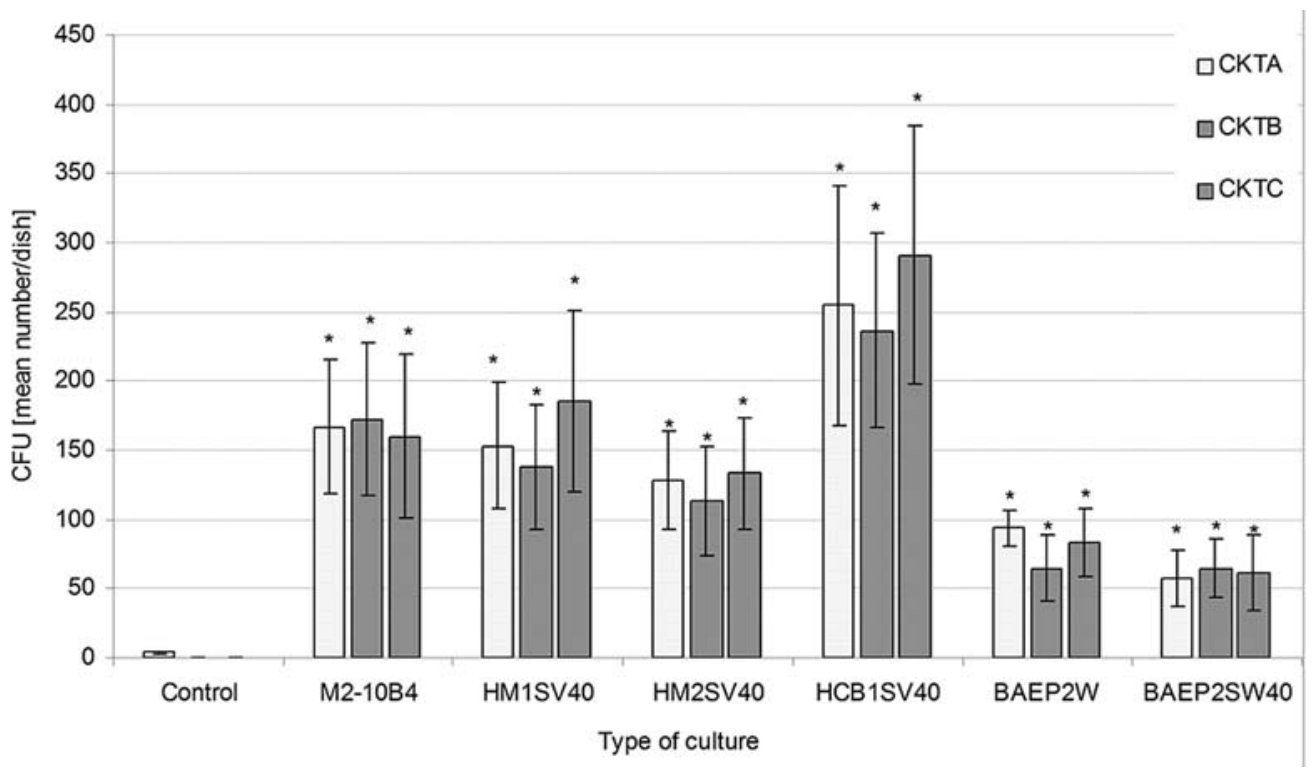

Figure 3. Effects of stromal feeder-layers and CKT treatment on MN cell clonal growth with respect to MN control cultures. Bars are means \pm SD ( $\mathrm{n}=10$ ). "p $<0.05$; Friedman and Dunn's multiple comparison tests.

Table III. Relative expansion indexes of co-cultures treated with different cytokine combinations (FL-CKTs) with respect to $\mathrm{MN}$ cultures established in the presence of the same cocktails (R.E.I.CKT).

\begin{tabular}{lccc}
\hline & \multicolumn{3}{c}{ R.E.I. ${ }_{\text {CKT }}$} \\
\cline { 2 - 4 } & FL+CKT A & FL+CKT B & FL+CKT C \\
\hline M210B4 & 1.5 & 1.6 & 0.9 \\
HM1SV40 & 1.4 & 1.3 & 1.1 \\
HM2SV40 & 1.2 & 1.1 & 0.8 \\
HCB1SV40 & 2.3 & 2.2 & 1.7 \\
BAEP2W & 0.9 & 0.6 & 0.5 \\
BAEP2SV40 & 0.5 & 0.6 & 0.4 \\
\hline
\end{tabular}

growth of the MN cells when compared to those determined in cultures grown in medium alone (Fig. 3). Higher increases were noted in feeder-layers composed of HCB1SV40 cells; E.I.s in the co-cultures ranged from 16 to 27 with fetal liver feeder-layers, from 32 to 53 with bone marrow feeder-layers, from 45 to 49 with mouse feeder-layers and from 67 to 83 with cord blood feeder-layers.

The E.I.s of co-cultures treated with the different cytokine combinations with respect to the MN cultures established in the presence of the same cocktails (R.E.I. . $_{\mathrm{CKT}}$ ) are provided in Table III. Higher increases were induced in the cytokinetreated feeder-layers composed of HCB1SV40 cells (ranging from 1.7 to 2.3). Feeder-layers of human bone marrow- and murine fibroblastic-derived cells induced a similar effect (R.E.I. Скт ranging from 1.1 to 1.6). Instead, clonogenic 


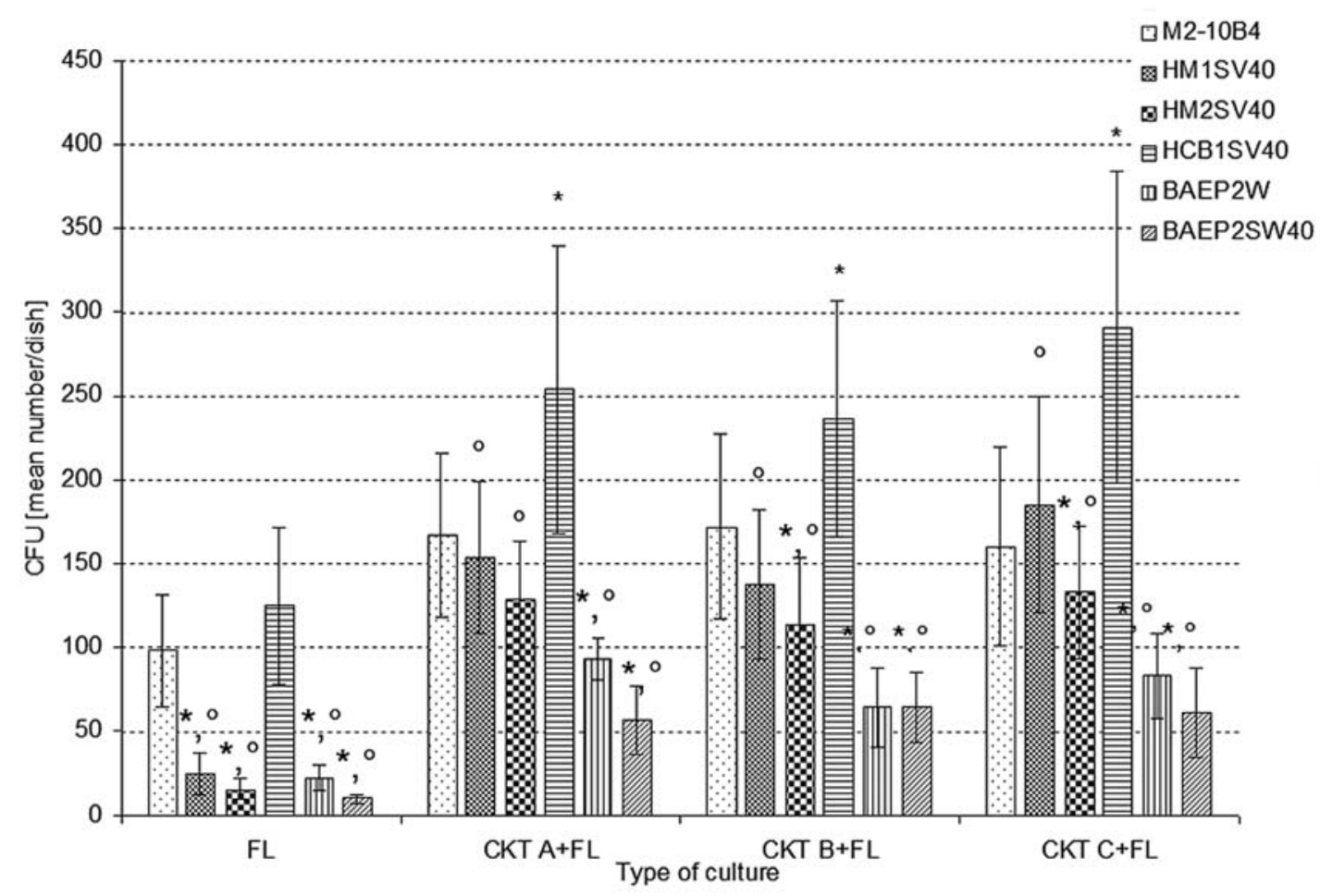

Figure 4. Effects of stromal feeder-layers and CKT treatment on MN cell clonal growth with respect to MN control co-cultures. Bars are means \pm SD ( $\mathrm{n}=10)$. ${ }^{*}, \mathrm{p}<0.05$ with respect to ${ }^{*} \mathrm{M} 2-10 \mathrm{~B} 4$ or $^{\circ} \mathrm{HCB} 1 \mathrm{SV} 40$; Friedman and Dunn's multiple comparison tests.

Table IV. Relative expansion indexes of co-cultures treated with different cytokine combinations (FL-CKTs) with respect to co-cultures established in the absence of cytokines (R.E.I. FL $_{\mathrm{L}}$ ).

\begin{tabular}{lccc}
\hline & \multicolumn{3}{c}{ R.E.I. $_{\text {FL }}$} \\
\cline { 2 - 4 } & FL+CKT A & FL+CKT B & FL+CKT C \\
\hline M210B4 & 1.7 & 1.76 & 1.6 \\
HM1SV40 & 6.1 & 5.40 & 7.3 \\
HM2SV40 & 8.5 & 7.60 & 8.9 \\
HCB1SV40 & 2.0 & 1.90 & 2.3 \\
BAEP2W & 4.3 & 2.90 & 3.8 \\
BAEP2SV40 & 5.8 & 6.50 & 6.2 \\
\hline
\end{tabular}

growth of MN cells cultured on fetal liver-derived cells in the presence of CKTs did not reach the levels observed using cytokine combinations alone. A similar trend was observed using HM2SV40 cells and CKT C.

The E.I.s of co-cultures treated with the different cytokine combinations with respect to the co-cultures established in the absence of cytokines (R.E.I.FL) are provided in Table IV. All CKTs enhanced the clonogenic growth of MN cells (R.E.I. FL $_{\text {L }}$ ranging from 1.6 to 8.9), with CKT C inducing the highest effect on all co-cultures (except for M2-10B4 and BAEP2W). Higher increases (ranging from 2.9 to 8.9) were noted in the feeder layers composed of human bone marrowand fetal liver-derived cells, while using HCB1SV40 or M210B4 cells as feeder-layers the improvement was $\sim 2$ and 1.5, respectively.
The CFU mean values determined in all co-cultures supplemented with CKTs are shown in Fig. 4. The clonogenic growth induced by HCB1SV40 feeder-layers was significantly $(\mathrm{p}<0.05)$ higher with respect to the growth observed in all of the other co-cultures. Although all CKT treatments induced a significant $(\mathrm{p}<0.05)$ enhancement in the CFU values in comparison with values determined in cocultures grown in medium alone, no significant variations were revealed among the various CKT supplementations. In order to analyze the expansion indexes of co-cultures with respect to $\mathrm{M} 2-10 \mathrm{~B} 4$, used as the control cell line, the R.E.I. $\mathrm{S}_{\mathrm{M} 2-10 \mathrm{~B} 4}$ were calculated. In the co-culture without CKT treatment, the R.E.I. $\mathrm{s}_{\mathrm{M} 2-10 \mathrm{~B} 4}$ ranged from 0.1 to 0.3 , with the exception of the HCB1SV40 cell line (R.E.I. ${ }_{\mathrm{M} 2-10 \mathrm{~B} 4}=1.3$ ). A similar trend was observed considering the R.E.I. ${ }_{\mathrm{M} 2-10 \mathrm{~B} 4}$ of the co-cultures supplemented with CKTs: the values observed ranged from 0.3 to 0.9 with the exception of the HCB 1 SV 40 cell line (1.3-1.8).

\section{Discussion}

One of the greatest challenges to clinical haematology and tissue engineering is the in vitro expansion of hematopoietic stem cells (HSCs). One of the problems related to the question of whether stem cells can be expanded in vitro, is the difficulty in the assay. To date, several strategies have been used to achieve HSC in vitro expansion (free culture with recombinant cytokines, conditioned supernatants, stromal feeder layers), with different expansive outputs (39-43). The strategy based on the co-culture of both hematopoietic stem cell candidates and large numbers of differentiated cells, grown in vitro over varying periods, has resulted in successful engraftment 
(22,44-47). Several studies have, in fact, documented an improved frequency of expansion of long-term cultureinitiating cells, colony-forming unit blast cells, and long-term repopulating cells in vivo by the co-culture of sorted HSC candidates, with either clonal cell lines derived from the bone marrow stromal microenvironment, or fresh cultures of stromal cells (48-50). Moreover, stromal cell lines have been proven to be an invaluable tool for the elucidation of the molecular mechanisms involved in the differentiation and self-renewal of hematopoietic cells $(27,51)$. Several studies have demonstrated the different inductive capacities of stromal (liver, spleen, bone marrow and fetal liver) feeder-layers to support and maintain hematopoietic proliferation $(52,53)$.

Besides the cellular microenvironment, an important role in HSC expansion seems to be played by molecular signaling and in particular by the presence of cytokines in the culture medium. However, one cytokine might have different effects on different types of cells, depending on the target cells, its concentration, and the presence of other cytokines. Hence the right cytokine, or cocktail of cytokines, for HSC expansion is still a critical issue (54).

In this study, we evaluated, in a middle-term culture of HSCs, the expansive effect of different cytokine cocktails (CKTs) and of self-made stromal cell lines, used alone or in combination with CKTs, for detecting the best culture condition(s) which can improve in vitro hematopoietic stem cell expansion.

All the cytokine cocktails used induced a significant and important increase in CB cell expansion indexes, and no potential variation depending on composition was evident. Although all cytokine cocktails A, B and C supported in vitro hematopoietic cord cell expansion, more proliferative effects were shown in the presence of cocktail $\mathrm{C}$. This result confirm the potential of IL-1B, EPO, G-CSF and GM-CSF to increase CFU numbers (54-57) and was in contrast to other studies in the literature $(41,58)$, which found that thrombopoietin (TPO) present in the cytokine cocktail B was not able to sustain middle-term stem cell proliferation and renewal, neither by itself nor in combination with other cytokines.

We previously characterized human bone marrow-derived (HM1SV40 and HM2SV40), umbilical cord-derived (HCB1SV40) and fetal liver-derived (BAEP2SV40 and BAEP2W) cell lines, used in this study as feeder-layers, and we showed that their conditioned supernatants were able to stimulate clonal growth of CB cells cultured on semi-solid medium deprived of exogenous growth factors and cytokines (32,33). Notably, ICC revealed that all cell lines did not only have a stromal cell-like phenotype, but also a mesenchymal cell-like phenotype, positive for 5'-nucleotidase (CD73), c-kit (CD117), and Flk-1 (CD309, KDR, VEGF-R), some of the mesenchymal markers. These data were confirmed by the RT-PCR result of VCAM-1 production in the immortalized cell lines.

Mesenchymal stem cells (MSCs), originally isolated from bone marrow (59), have been successively obtained from different tissues such as cord blood, adipose tissue, placenta and amniotic fluid, fetal liver tissue, pulmonary parenchyma and the pulp of deciduous teeth (60). In past years, researchers have attempted to define the expression patterns of cell surface antigen employing different panels of polyclonal and monoclonal antibodies $(61,62)$. However, similar to other stem cell types, they failed to detect specific markers for MSCs, and the precise phenotype of these cells has yet to be determined. Several phenotypes for cultured human MSCs have been reported, and these include expression for CD73, CD117, CD 106 and CD309 (63-67). Therefore, our cell lines had characteristics similar to MSCs present in adult bone marrow and in other human tissues and, similar to these cells, they were non-hematopoietic and CD34-, CD14-, CD15-, CD42b- (68).

However, the phenotypic profile of our cell lines showed the expression of $\alpha$-actin in the HM2SV40, HBC1SV40, BAEP2W and BAEP2 SV40 cell lines, and FGF-R in the HM1SV40, HM2SV40, HBC1SV40 and BAEP2W cell lines in contrast to previous observations at the moment of their isolation (32,33). Moreover, the HCB1SV40 cell line was positive for fibronectin and laminin, while HM1SV40 and BAEP2SV40 cell lines were negative for laminin and EGF$\mathrm{R}$, respectively. The causes of these phenotypical variations need to be defined. Yet, we hypothesize that long-term culture (more than one year) or culture temperature $\left(37^{\circ} \mathrm{C}\right)$ or both culture conditions could be the primary causes. All the cell lines, with the exception of BAEP2W, were immortalized by transduction with a retroviral MoMuLV, containing a mutant temperature-sensitive Simian virus 40 (SV40) large T antigen. The protein coded by this gene induces cellular proliferation at the permissive temperature of $33^{\circ} \mathrm{C}$, whereas it is inactive at the non-permissive temperature of $39^{\circ} \mathrm{C}$, inducing cellular growth arrest in the G0 phase and cellular differentiation (69). Hence, the culture temperature used was sub-optimal to induce either cellular growth and differentiation. As a consequence, it is important to verify whether an immortalized cell line long-term culture induces expression of other mesenchymal markers at $33^{\circ} \mathrm{C}$ and a stromal phenotypical profile at $39^{\circ} \mathrm{C}$.

Our results showed that all feeder-layers were able to induce significant clonogenic growth with respect to the control cells. In particular, the HCB1SV40 cell line supported a middle-term culture of cord cells, similar to reference line M2-10B4, as previously demonstrated by Breems et al (70) in FBMD-1, L87/4 and L87/5 stromal lines. On the contrary, bone marrow stromal cells (HM1SV40 and HM2SV40) and hepatic immortalized stromal lines (BAEP2W and BAEP2SV40) revealed expansive indexes much lower than the M210B4 cell line.

Addition of cytokines to the co-cultures clearly increased the expansive indexes of all the cell lines dependent on the composition and synergies with used cell lines. In fact CKTs significantly increased the expansive potential of HCB1SV40 and HM1SV40 cell lines more than the cytokine cocktails alone. The different synergism between feeder-layers and cytokine cocktails could be related to previous data which showed that our cell lines, used for feeder-layers, not only expressed the mRNA of several growth factors, such as GMCSF, G-CSF, IL-6 but also secreted them in the culture medium $(32,33)$.

In light of these considerations, stromal cell line HCB1SV40 may be used in co-culture systems as a feeder layer in combination with cytokines for improving in vitro expansion of CB HSCs. Nevertheless, the potential of the 
cocktails to increase in vitro expansion of cord hematopoietic cells requires further detailed study to consider their further use in developing cellular expansion techniques for allogenic transplantation. Moreover, further studies are needed to detect the interactions between stromal and haematopoietic progenitor cells in this expansion cell culture model.

In conclusion, we investigated the middle-term expansion of hematopoietic CB cells and found that the cytokine cocktails and stromal feeder-layers used in this study clearly increased the in vitro expansion indexes of $\mathrm{CB}$ cells. In particular, CKT C and stromal cell line HCB1SV40 were the most effective. Moreover, we demonstrated that exogenous cytokines and stromal feeder-layers may act in synergism in in vitro hematopoietic progenitor cell expansion.

\section{References}

1. Quesenberry PJ and Colvin GA: Hematopoietic stem cells, progenitor cells, and growth factors. In: Williams Hematology. Beutler E, Lichtman MA, Coller BS and Kipps TJ (eds). 5th edition, McGraw-Hill, New York, pp153-174, 1991.

2. Metcalf D: Mechanisms of human hematopoiesis. In: Hematopoietic Cell Transplantation. Thomas ED, Blume KG and Forman SJ (eds). 2nd edition, Blackwell Science, Madden, pp48-87, 1999.

3. Smith C: Hematopoietic stem cells and hematopoiesis. Cancer Control 10: 9-16, 2003.

4. Dexter TM, Allen TD and Lajtha LG: Conditions controlling the proliferation of haematopoietic stem cells in vitro. J Cell Physiol 91: 335-344, 1977.

5. Steidl U, Kronenwett R, Martin S and Haas R: Molecular biology of hematopoietic stem cells. Vitam Horm 66: 1-28, 2003.

6. Arai F, Hirao A and Suda T: Regulation of hematopoietic stem cells by the niche. Trends Cardiovasc Med 15: 75-79, 2005.

7. Han W, Yu Y and Liu XY: Local signals in stem cell-based bone marrow regeneration. Cell Res 16: 189-195, 2006.

8. Janowska-Wieczorek A, Majka M, Ratajczak J and Ratajczak MZ: Autocrine/paracrine mechanisms in human hematopoiesis. Stem Cells 19: 99-107, 2001.

9. Consolini R, Legitimo A and Calleri A: La cellula staminale ematopoietica: biologia e applicazioni cliniche. Pathologica 93: $2-14,2001$.

10. Majumdar MK, Thiede MA, Haynesworth SE, Bruder SP and Gerson SL: Human marrow-derived mesenchymal stem cells (MSCs) express hematopoietic cytokines and support long-term hematopoiesis when differentiated toward stromal and osteogenic lineages. J Hematother Stem Cell Res 9: 841-848, 2000.

11. Gonçalves R, Lobato da Silva C, Cabral JM, Zanjani ED and Almeida-Porada G: A Stro-1(+) human universal stromal feeder layer to expand/maintain human bone marrow hematopoietic stem/progenitor cells in a serum-free culture system. Exp Hematol 34: 1353-1359, 2006.

12. Jang YK, Jung DH, Jung MH, Kim DH, Yoo KH, Sung KW, Koo HH, Oh W, Yang YS and Yang SE: Mesenchymal stem cells feeder layer from human umbilical cord blood for ex vivo expanded growth and proliferation of hematopoietic progenitor cells. Ann Hematol 85: 212-225, 2006.

13. Robinson SN, Ng J, Niu T, Yang H, McMannis JD, Karandish S, Kaur I, Fu P, Del Angel M, Messinger R, Flagge F, de Lima M, Decker W, Xing D, Champlin R and Shpall EJ: Superior ex vivo cord blood expansion following co-culture with bone marrowderived mesenchymal stem cells. Bone Marrow Transplant 37: 359-366, 2006.

14. Burroughs J, Gupta P, Blazar BR and Verfaillie CM: Diffusible factors from the murine cell line M2-10B4 support human in vitro hematopoiesis. Exp Hematol 22: 1095-1101, 1994.

15. Gupta P, Oegema TR, Brazil JJ, Dudek AZ, Slungaard A and Verfaillie CM: Structurally specific heparan sulfates support primitive human hematopoiesis by formation of a multimolecular stem cell niche. Blood 92: 4641-4651, 1998.

16. Bilko NM, Votyakova IA, Vasylovska SV and Bilko DI: Characterization of the interactions between stromal and haematopoietic progenitor cells in expansion cell culture models. Cell Biol Int 29: 83-86, 2005.
17. Nakahata T: Ex vivo expansion of human hematopoietic stem cells. Int J Hematol 73: 6-13, 2001.

18. Heike T and Nakahata T: Ex vivo expansion of hematopoietic stem cells by cytokines. Biochim Biophys Acta 1952: 313-321, 2002.

19. Gilmore GL, DePasquale DK, Lister J and Shadduck RK: Ex vivo expansion of human umbilical cord blood and peripheral blood CD34(+) hematopoietic stem cells. Exp Hematol 28: 1297-1305, 2000.

20. Lorenzon D, Mazzucato M, Abbruzzese L, Cilli M, De Angeli S, Degan M, Mambrini G, Piccardi F, Rupolo M, Michieli M, De Marco L, Gattei V and Astori G: Preclinical ex vivo expansion of peripheral blood $\mathrm{CD} 34^{+}$selected cells from cancer patients mobilized with combination chemotherapy and granulocyte colony-stimulating factor. Vox Sang 94: 342-350, 2008.

21. Zhang Y, Chai C, Jiang XS, Teoh SH and Leong KW: Coculture of umbilical cord blood CD $34^{+}$cells with human mesenchymal stem cells. Tissue Eng 12: 2161-2170, 2006.

22. Devine SM, Lazarus HM and Emerson SG: Clinical application of hematopoietic progenitor cell expansion: current status and future prospects. Bone Marrow Transplant 31: 241-252, 2003.

23. Broxmeyer HE, Douglas GW, Hangoc G, Cooper S, Bard J, English D, Arny M, Thomas L and Boyse EA: Human umbilical cord blood as a potential source of transplantable hematopoietic stem/progenitor cells. Proc Natl Acad Sci USA 86: 3828-3832, 1989.

24. Frassoni F, Podestà M, Maccario R, Giorgiani G, Rossi G, Zecca M, Bacigalupo A, Piaggio G and Locatelli F: Cord blood transplantation provides better reconstitution of hematopoietic reservoir compared with bone marrow transplantation. Blood 102: 1138-1141, 2003.

25. Heimfeld S: HLA-identical stem cell transplantation: Is there an optimal CD34 cell dose? Bone Marrow Transplant 31: 839-846, 2003.

26. McAdams TA, Miller WM and Papoutsakis ET: Hematopoietic cell culture therapies (part I): Cell culture considerations. Trends Biotechnol 14: 341-349, 1996.

27. Del Pup L, Belloni AS, Carraro G, De Angeli S, Parnigotto PP and Nussdorfer GG: Adrenomedullin is expressed in cord blood hematopoietic cells and stimulates their clonal growth. Int J Mol Med 11: 157-160, 2003.

28. De Angeli S, Del Pup L, Durante E, Parnigotto PP, Nussdorfer GG and Gajo GB: Adrenomedullin and endothelin-1: two new growth factors for in vitro expansion of hematopoietic cord blood cells. Cell Pres Technol 4: 56-68, 2006.

29. Yang M, Li K, Ng PC, Chuen CK, Lau TK, Cheng YS, Liu YS, Li CK, Yuen PM, James AE, Lee SM and Fok TF: Promoting effects of serotonin on hematopoiesis: ex vivo expansion of cord blood CD34 ${ }^{+}$stem/progenitor cells, proliferation of bone marrow stromal cells, and antiapoptosis. Stem Cells 25: 1800-1806, 2007.

30. Ehring B, Biber K, Upton TM, Plosky D, Pykett M and Rosenzweig M: Expansion of HPCs from cord blood in a novel 3D matrix. Cytotherapy 5: 490-499, 2003.

31. Liu Y, Liu T, Fan X, Ma X and Cui Z: Ex vivo expansion of hematopoietic stem cells derived from umbilical cord blood in rotating wall vessel. J Biotechnol 124: 592-601, 2006.

32. Del Pup L, De Angeli S, Conconi MT, Grandi C, Gamba PG, Parnigotto PP and Nussdorfer GG: New human embryo liver cell lines obtained by stabilization and immortalization enhance in vitro clonal growth of cordonal blood cells. Int J Mol Med 10: 561-568, 2002.

33. De Angeli S, Di Liddo R, Buoro S, Toniolo L, Conconi MT, Belloni AS, Parnigotto PP and Nussdorfer GG: New immortalized human stromal cell lines enhancing in vitro expansion of cord blood hematopoietic stem cells. Int J Mol Med 13: 363-371, 2004.

34. Chapel $\mathrm{H}$ and Sewell H: Cellular assay for lymphoid immune deficiency. In: Clinical Immunology: A Practical Approach. Gooi HC and Chapel H (eds). IRL Press, Oxford, pp23-36, 1990.

35. Hogge DE, Lansdorp PM, Reid D, Gerhard B and Eaves CJ: Enhanced detection, maintenance, and differentiation of primitive human hematopoietic cells in cultures containing murine fibroblasts engineered to produce human steel factor, interleukin-3, and granulocyte colony-stimulating factor. Blood 88: 3765-3773, 1996.

36. Mazzocchi G, Rossi GP, Neri G, Malendowicz LK, Albertin G and Nussdorfer GG: 11Beta-hydroxysteroid dehydrogenase expression and activity in the human adrenal cortex. FASEB J 12: $1533-1539,1998$ 
37. Miller CL and Lai B: Human and mouse hematopoietic colonyforming cell assays. In: Basic Cell Culture Protocols. Helgason CD and Miller C (eds). Humana Press, Totowa, New Jersey, pp71-90, 2005.

38. Nissem-Druey C, Tichelli A and Meyer-Monard S: Human Hematopoietic Colonies in Health and Disease. Acta Haematologica, Karger, Basel, pp5-96, 2005.

39. Ohmizono Y, Sakabe H, Kimura T, Tanimukai S, Matsumura T, Miyazaki H, Lyman SD and Sonoda Y: Thrombopoietin augments ex vivo expansion of human cord blood-derived hematopoietic progenitors in combination with stem cell factor and flt3 ligand. Leukemia 11: 524-530, 1997.

40. Yonemura Y, Ku H, Lyman SD and Ogawa M: In vitro expansion of hematopoietic progenitors and maintenance of stem cells: comparison between FLT3/FLK-2 ligand and KIT ligand. Blood 89: 1915-1921, 1997.

41. Piacibello W, Sanavio F, Garetto L, Severino A, Bergandi D, Ferrarlo J, Fagioli F, Berger M and Aglietta M: Extensive amplification and self-renewal of human primitive hematopoietic stem cells from cord blood. Blood 89: 2644-2653, 1997.

42. Piacibello W, Sanavio F, Garetto L, Severino A, Dané A, Gammaitoni L and Aglietta M: Differential growth factor requirement of primitive cord blood hematopoietic stem cells for self-renewal and amplification vs proliferation and differentiation. Leukemia 12: 718-727, 1998.

43. Takagi M: Cell processing engeneering for ex-vivo expansion of hematopoietic cells. J Biosci Bioeng 99: 189-196, 2005.

44. Brugger W, Heimfeld S, Berenson RJ, Mertelsmann R and Kanz L: Reconstitution of hematopoiesis after high-dose chemotherapy by autologous progenitor cells generated ex vivo. N Engl J Med 333: 283-287, 1995.

45. Kusadasi N, van Soest PL, Mayen AE, Koevoet JL and Ploemacher RE: Successful short-term ex vivo expansion of NOD/SCID repopulating ability and CAFC week 6 from umbilical cord blood. Leukemia 14: 1944-1953, 2000.

46. Lam AC, Li K, Zhang XB, Li CK, Fok TF, Chang AM, James AE, Tsang KS and Yuen PM: Preclinical ex vivo expansion of cord blood hematopoietic stem and progenitor cells: duration of culture; the media, serum supplements, and growth factors used; and engraftment in NOD/SCID mice. Transfusion 41: 1567-1576, 2001.

47. Zhang CC and Lodish HF: Cytokines regulating hematopoietic stem cell function. Curr Opin Hematol 15: 307-311, 2008.

48. Civin CI, Almeida-Porada G, Lee MJ, Olweus J, Terstappen LW and Zanjani ED: Sustained, retransplantable, multilineage engraftment of highly purified adult human bone marrow stem cells in vivo. Blood 88: 4102-4109, 1996.

49. Lu LS, Wang SJ and Auerbach R: In vitro and in vivo differentiation into B cells, T cells, and myeloid cells of primitive yolk sac hematopoietic precursor cells expanded $>100$-fold by coculture with a clonal yolk sak endothelial cell line. Proc Natl Acad Sci USA 93: 14782-14787, 1996.

50. Bathia M, Wang JCY, Kapp U, Bonnet D and Dick JE: Purification of primitive, human hematopoietic cells capable of repopulating immune-deficient mice. Proc Natl Acad Sci USA 94: 5320-5325, 1997.

51. Muller-Sieburg CE and Deryugina E: The stromal cell guide to the stem cell universe. Stem Cells 13: 477-486, 1995.

52. Van den Heuvel R, Schoeters G, Leppens H and Vanderborght O: Stromal cells in long-term culture of liver, spleen and bone marrow at different developmental ages have different capacities to maintain GM-CFC proliferation. Exp Hematol 19: 115-121, 1991

53. Wineman J, Moore K, Leminschka I and Muller-Sieburg C: Functional heterogeneity of the hematopoietic microenvironment: rare stromal elements maintain long-term repopulating stem cells. Blood 87: 4082-4090, 1996.
54. Yao CL, Chu IM, Hsieh TB and Hwang SM: A systematic strategy to optimize ex vivo expansion medium for human hematopoietic stem cells derived from umbilical cord blood mononuclear cells. Exp Hematol 32: 720-727, 2004.

55. Mayani H, Dragowska W and Lansdorp PM: Cytokine-induced selective expansion and maturation of erythroid versus myeloid progenitors from purified cord blood precursor cells. Blood 81: 3252-3258, 1993.

56. Petzer AL, Hogge DE, Lansdorp PM, Reid DS and Eaves CJ: Self-renewal of primitive human hematopoietic cells (longterm-culture-initiating cells) in vitro and their expansion in defined medium. Proc Natl Acad Sci USA 93: 1470-1474, 1996.

57. Poloni A, Giarratana MC, Firat H, Kobari L, Gorin NC and Douay L: The ex vivo expansion capacity of normal human bone marrow cells is dependent on experimental conditions: role of the cell concentration, serum and $\mathrm{CD} 34^{+}$cell selection in stromafree cultures. Hematol Cell Ther 39: 49-58, 1997.

58. Petzer AL, Zandstra PW, Piret JM and Eaves CJ: Differential cytokine effects on primitive $\left(\mathrm{CD} 34^{+} \mathrm{CD} 38^{-}\right)$human hematopoietic cells: novel responses to Flt3-ligand and thrombopoietin. J Exp Med 183: 2551-2558, 1996.

59. Friedenstein AJ, Petrakova KV, Kurolesova AI and Frolova GP: Etherotopic transplants of bone marrow analysis of precursor cells for osteogenic and hematopoietic tissues. Transplantation 6: 230-247, 1968.

60. Bobis S, Jarocha D and Majka M: Mesenchymal stem cells: characteristics and clinical applications. Folia Histochem Cytobiol 44: 215-230, 2006.

61. He Q, Wan C and Li G: Concise review: multipotent mesenchymal stromal cells in blood. Stem Cells 25: 69-77, 2007.

62. Chamberlain G, Fox J, Ashton B and Middleton J: Concise review: mesenchymal stem cells: their phenotype, differentiation capacity, immunological features, and potential for homing. Stem Cells 25: 2739-2749, 2007.

63. Cognet PA and Minguell JJ: Phenotypical and functional properties of human bone marrow mesenchymal progenitor cells. J Cell Physiol 181: 67-73, 1999.

64. Dennis JE, Carbillet JP, Caplan AI and Charbord P: The STRO $-1^{+}$marrow cell population is multipotential. Cells Tissues Organs 170: 73-82, 2002.

65. Baddoo M, Hill K, Wilkinson R, Gaupp D, Hughes C, Kopen GC and Phinney DG: Characterization of mesenchymal stem cells isolated from murine bone marrow by negative selection. J Cell Biochem 89: 1235-1249, 2003.

66. Gronthos S, Zannettino AC, Hay DJ, Shi S, Graves SE, Kortesidis A and Simmonos PJ: Molecular and cellular characterization of highly purified stromal stem cells derived from human bone marrow. J Cell Sci 116: 1827-1835, 2003.

67. Boiret N, Rapatel C, Veyrat-Masson R, Guillouard L, Guérin J-J, Pigeon P, Descamps S, Boisgard S and Berger MG: Characterization of non-expanded mesenchymal progenitor cells from normal adult human bone marrow. Exp Hematol 33: 219-225, 2005.

68. Pittenger MF, Mackay AM, Beck SC, Jaiswal RK, Douglas R, Mosca JD, Moorman MA, Simoneti DW, Craig S and Marshak DR: Multilineage potential of adult human mesenchymal stem cells. Science 284: 143-147, 1999.

69. Jat PS and Sharp PA: Cell lines established by a temperaturesensitive simian virus 40 large-T-antigen gene are growth restricted at the nonpermissive temperature. Mol Cell Biol 9: 1672-1681, 1989.

70. Breems DA, Blokland EA, Siebel KE, Mayen AE, Engels LJ and Ploemacher RE: Stroma-contact prevents loss of hematopoietic stem cell quality during ex vivo expansion of CD $34^{+}$mobilized peripheral blood stem cells. Blood 91: 111117, 1998. 